\title{
HEMATOLOGICAL AND INTESTINAL RESPONSES OF BROILERS TO DIETARY SUPPLEMENTATIONS OF LACTIC FERMENTED TURMERIC, BLACK PEPPER OR A MIXTURE OF BOTH
}

\author{
Sugiharto Sugiharto ${ }^{1}$, Endang Widiastuti ${ }^{1}$, Anugrah Robby Pratama ${ }^{1}$, \\ Hanny Indrat Wahyuni ${ }^{1}$, Turrini Yudiarti ${ }^{1}$, Tri Agus Sartono ${ }^{1}$

\footnotetext{
${ }^{1}$ Department of Animal Science, Faculty of Animal and Agricultural Sciences, Universitas Diponegoro, Semarang, Central Java, Indonesia (50275)
}

Link to this article: https://doi.org/10.11118/actaun.2021.011

Received: 18. 9. 2020, Accepted: 6. 1. 2021

To cite this article: SUGIHARTO SUGIHARTO, WIDIASTUTI ENDANG, PRATAMA ANUGRAH ROBBY, WAHYUNI HANNY INDRAT, YUDIARTI TURRINI, SARTONO TRI AGUS. 2021. Hematological and Intestinal Responses of Broilers to Dietary Supplementations of Lactic Fermented Turmeric, Black Pepper or a Mixture of Both. Acta Universitatis Agriculturae et Silviculturae Mendelianae Brunensis, 69(1): 101-110.

\begin{abstract}
The present experiment investigated the impact of administrations of lactic fermented turmeric, black pepper or a mixture of both into diets on the hematological parameters and intestinal ecology and morphology of broilers. Three hundred and ninety two broilers were spread to T0 (control), T1 (feed administrated with 1\% lactic fermented turmeric), T2 (feed administrated with 1\% lactic fermented black pepper) and T3 (feed administrated with 1\% lactic fermented turmeric and 1\% lactic fermented black pepper). Blood sampling was conducted at days 21 and 35, while intestinal sampling was at day 35. At day 21, erythrocyte counts were greater $(P \leq 0.05)$ for $\mathrm{T} 1$ compared to that for T2 and T3. Broilers in T1 had deceased $(P \leq 0.05)$ serum total triglyceride compared to that of T0 and T3. The concentration of globulin was reduced $(P \leq 0.05)$ in T3 than that in T0 and T1. At day 35, serum triglyceride level was more elevated $(P \leq 0.05)$ in T0 compared to that in T2 and T3 groups. Serum cholesterol as well as low-density lipoprotein levels were lower $(P \leq 0.05)$ in T3 than that in T0. Compared to other broilers, total protein and globulin concentrations were lower $(P \leq 0.05)$ in T3. A bigger $(P \leq 0.05)$ ratio of albumin to globulin $(\mathrm{A} / \mathrm{G})$ was seen in T3 compared to that in T1 and T2. Creatinine was greater $(P \leq 0.05)$ in T1 than in others. The titer of antibody toward vaccine of Newcastle disease was elevated $(P \leq 0.05)$ in T1 and T2 than in T0. The LAB counts were enhanced $(P \leq 0.05)$ in ileum of $\mathrm{T} 1$ and T2 than that in T0. Compared to T0, the villi height of jejunum was elevated $(P \leq 0.05)$ in treated broilers. In conclusion, administration of fermented turmeric powder improved erythrocyte counts, antibody titer toward Newcastle disease vaccine, LAB population and jejunal villi height of broilers.
\end{abstract}

Keywords: broilers, herbs, immune response, intestinal ecology, lactic fermentation

\section{INTRODUCTION}

Phytogenic or herbal ingredients have long been exploited as feed additives in broiler farms. Currently, dietary herbal application is becoming more popular among poultry nutritionists following the retraction of antibiotic growth promoters from broiler diets. Turmeric (Curcuma longa Linn.) is one of the herbs most widely employed as a dietary additive for broilers. The dietary administration of turmeric root powder has been reported not only to improve the production performance, but also to improve the physiological and health conditions 
of broilers (Attia et al., 2017; Guil-Guerrero et al., 2017; Ürüşan and Bölükbaşı, 2017). Other herbal product that has widely been incorporated in broiler feeds is black pepper (Piper nigrum). Dietary supplementation of black pepper has been shown to promote growth rate and improve the blood lipid indices of broilers (Puvača et al., 2014). Likewise, Abou-Elkhair et al. (2014) and Ndelekwute et al. (2015) documented that supplementation of black pepper in diets improved growth performance and health of broilers.

Lactic acid fermentation is one of the simple methods to enhance the functional properties of herbs. Rizzello et al. (2013) documented that lactic acid bacteria (LAB) fermentation increased the antimicrobial, antioxidants and immunomodulatory activities of Echinacea spp. Also, Ng et al. (2011) reported that lactic acid fermentation resulted in increased antioxidant capacity of herbal Anoectochilus formosanus. Moreover, Nazarni et al. (2016) reported that LAB fermentation increased antibacterial and antioxidant activities of Crataeva nurvala HAM (tigarun). With regard to LAB, these gram positive bacteria have been isolated from many sources, including wild fruits (Rodríguez et al., 2019). In agreement with the latter report, we have recently confirmed that the underutilized fruit Averrhoa bilimbi L. could be a good source of LAB (Mareta et al., 2020), and thus can be used to ferment the herbs. The fruit also contains amino acids, carbohydrates, organic acids, minerals, vitamin C and other nutrients (Peris et al., 2013; Alhassan and Ahmed 2016), which may be essential to support the growth of LAB. In this study, turmeric root and black pepper powders were lactic fermented with the fruit filtrate of $A$. bilimbi $\mathrm{L}$. prior to the administration to broiler diets. To best of our view, no other investigation reported the use of lactic fermented turmeric, black pepper of a mixture of both as feed additive for broilers so far.

The present study evaluated the impact of administrations of lactic fermented turmeric, black pepper or a mixture of both on the hematological indices and intestinal bacterial population and morphology of broilers.

\section{MATERIALS AND METHODS}

\section{Production of Lactic Fermented Herbs}

The filtrate of $A$. bilimbi fruit was firstly made prior to production of lactic fermented herbs. The mature A. bilimbi fruit was collected from the park surrounding the campus. It was washed, drained and then blended (without adding water) by means of electronic blender. The fruit juice was filtrated using cheesecloth. The sample of fruit filtrate was obtained for the determination of $\mathrm{pH}$ value and number of lactic acid bacteria. The pH measurement using electronic pH meter (Thermo Fisher Scientific Inc.) showed that $\mathrm{pH}$ value of the fruit filtrate was about 1.45. The number of LAB in the filtrate was determined according to viable count method using de Man, Rogosa and Sharpe (MRS) agar. Following the incubation under anaerobic condition for 48 hours at $38^{\circ} \mathrm{C}$, the colonies of LAB in the fruit filtrate were $6.69 \log \mathrm{cfu} / \mathrm{mL}$.

The herbs were purchased at the local Semarang market. For the production of lactic fermented herbs, turmeric or black pepper powder was mixed with the filtrate of $A$. bilimbi fruit $(1: 3 ; \mathrm{g}: \mathrm{mL})$ and then put in an anaerobic jar. Following the room temperature-incubation for 4 days, the mixture was sun-dried and then sampled for $\mathrm{pH}$ values and LAB counts determination. The remainder was stored at refrigerator until use. The $\mathrm{pH}$ measurement on turmeric powder showed that the $\mathrm{pH}$ values decreased from 5.90 to 3.70 following lactic fermentation using $A$. bilimbi fruit filtrate, and from 5.80 to 3.00 in black pepper powder after fermentation. The counts of LAB in turmeric powder increased from 8.17 to $10.9 \log \mathrm{cfu} / \mathrm{mL}$ and from 8.47 to $11.3 \log \mathrm{cfu} / \mathrm{mL}$ in black pepper powder after lactic fermentation.

\section{In Vivo Experiment}

The broiler trial was organized according to a completely randomized arrangement involving 392 day-old chicks (Lohmann meat broiler, average live weight of $38.98 \pm 1.14 \mathrm{~g}$ ). The chicks were indiscriminately spread to four groups of treatments, each of which incorporated of 7 replicates/pens with 14 birds in each. The group of treatments included T0 (control, additive free diet), T1 (diet administrated with 1\% lactic fermented turmeric), T2 (diet administrated with 1\% lactic fermented black pepper) and T3 (diet administrated with 1\% lactic fermented turmeric and 1\% lactic fermented black pepper). A broiler house with open sides was used to raise the chicks for the entire experiment. The rice husk was used as litter material. The pen was $1.10 \times 1.10 \mathrm{~m}^{2}$ and facilitated with hand-operated feeder and drinker. Light was provided throughout the day during the trial. The birds were provided with commercial pre-starter feed, containing 23\% total protein, 5\% total fat, 5\% total fiber and $7 \%$ ash (chemical compositions were based on feed label), from arrival to day 7. From days 8 to 21, the birds were offered with formulated starter feed, and from days 22 to 35 with finisher feed. The constituents of the formulated feeds are provided in Tab. I. The lactic fermented turmeric or black pepper were incorporated (“on top") to feeds from days 1 to 35. Vaccination with Newcastle disease vaccine (NDV) via eye was performed on day 4, while through drinking water on day 18.

On days 21 and 35, two male chicks with body weight close to pen average body weight were taken (14 chicks for each treatment group) and blood was withdrawn from their wing veins and subsequently put in tube with anticoagulant (ethylenediaminetetraacetic acid/EDTA) for the 
I: Constituents and nutritional compositions of broiler rations

\begin{tabular}{|c|c|c|}
\hline Items (\%, except that otherwise mentioned) & Starter $(8-21)$ & Finisher (22-35) \\
\hline Corn & 55.9 & 62.5 \\
\hline SBM & 37.1 & 29.5 \\
\hline Palm oil & 2.22 & 3.22 \\
\hline DL-methionine & 0.19 & 0.19 \\
\hline Bentonite & 1.00 & 1.00 \\
\hline Limestone powder & 1.34 & 1.34 \\
\hline $\mathrm{MCP}$ & 1.51 & 1.51 \\
\hline Mineral-vitamin mix & 0.27 & 0.27 \\
\hline Chlorine chlorite & 0.07 & 0.07 \\
\hline $\mathrm{NaCl}$ & 0.40 & 0.40 \\
\hline \multicolumn{3}{|c|}{ Calculated nutritional compositions: } \\
\hline $\mathrm{ME}^{1}(\mathrm{kcal} / \mathrm{kg})$ & 2,900 & 3,040 \\
\hline $\mathrm{CP}$ & 21.0 & 18.0 \\
\hline $\mathrm{CF}$ & 5.50 & 5.50 \\
\hline $\mathrm{Ca}$ & 1.30 & 1.30 \\
\hline $\mathrm{P}$ & 0.60 & 0.60 \\
\hline \multicolumn{3}{|c|}{ Analyzed nutritional compositions: } \\
\hline $\mathrm{ME}^{1}(\mathrm{kcal} / \mathrm{kg})$ & 3,144 & 3,219 \\
\hline DM & 90.1 & 89.2 \\
\hline $\mathrm{CP}$ & 19.0 & 16.9 \\
\hline $\mathrm{EE}$ & 3.30 & 3.44 \\
\hline $\mathrm{CF}$ & 8.69 & 9.40 \\
\hline Ash & 9.77 & 7.10 \\
\hline
\end{tabular}

assessment of whole blood numbers. The remainder blood was harboured in EDTA-free tube for yielding blood serum after clotting at room temperature for about 2 hours. Male chicks were chosen for blood sampling to avoid the physiological error due to gender variations. For the practical reason, the chicks that were previously blood sampled were killed, and the internal organs were then eviscerated. For the quantification of gut bacterial populations, digesta was squeezed from ileum and caecum and put in the sterile sample containers. Digesta was also collected from duodenum, jejunum, ileum and caecum for the measurement of $\mathrm{pH}$ values (using electronic $\mathrm{pH}$ meter; Thermo Fisher Scientific Inc.). For the small intestinal morphology assessment, the segments (approximately $2 \mathrm{~cm}$ in length) was obtained from each small intestinal segment and put in sample tubes containing solution of 10\% neutral formalin buffer.

Determination of complete blood numbers was carried out using a Prima Fully-Auto Hematology Analyzer (PT. Prima Alkesindo Nusantara, Jakarta, Indonesia) following the producer's protocol. The antibody toward NDV was quantified following the hemagglutination inhibition (HI) method (Villegas, 1987), and the titer was provided as geometric mean titres $\left(\log _{2}\right)$. Biochemical assessment in serum including lipid profile, creatinine and uric acid were carried out according to the colorimetric/enzymatic color test. The calculations of total protein, albumin, alanine aminotransferase (ALT) as well as aspartate aminotransferase (AST) were carried out following the spectrophotometric/photometric method. The concentration of serum globulin was calculated from reduction of overall protein with albumin. A commercial assay (DiaSys Diagnostic System GmbH, Holzheim, Germany) was used as the standard during serum biochemical analysis. To perform histological analysis, duodenal, jejunal or ileal slices ( $5 \mu \mathrm{m}$ each) were dyed using haematoxylin and also eosin. The measurement of villus height and crypt depth was then conducted with optical microscope facilitated with camera. Coliform as well as lactosenegative enterobacteriaceae populations in the gut contents were counted as red and colorless colonies 
on MacConkey agar following incubation (aerobic) at $38^{\circ} \mathrm{C}$ for 24 hours. The number of coliform bacteria and lactose negative enterobacteriaceae bacteria was concluded as enterobacteria. The amount of LAB in digesta was determined on the MRS agar as described above.

Results were statistically assigned according to ANOVA (SPSS 16.0 version). Duncan's post-hoc test was additionally run if notable impact $(P \leq 0.05)$ of treatments was seen on the parameters measured.

\section{RESULTS}

\section{Complete Blood Counts of Broilers}

Data regarding whole blood profiles of birds are provided on Tab. II. On day 21, the numbers of erythrocytes were elevated $(P \leq 0.05)$ in $\mathrm{T} 1$ compared to that in $\mathrm{T} 2$ and $\mathrm{T} 3$, but did not vary from T0 broilers. The other blood indices did not vary $(P>0.05)$ across the groups both at days 21 and 35 .

II: Whole blood numbers of broilers

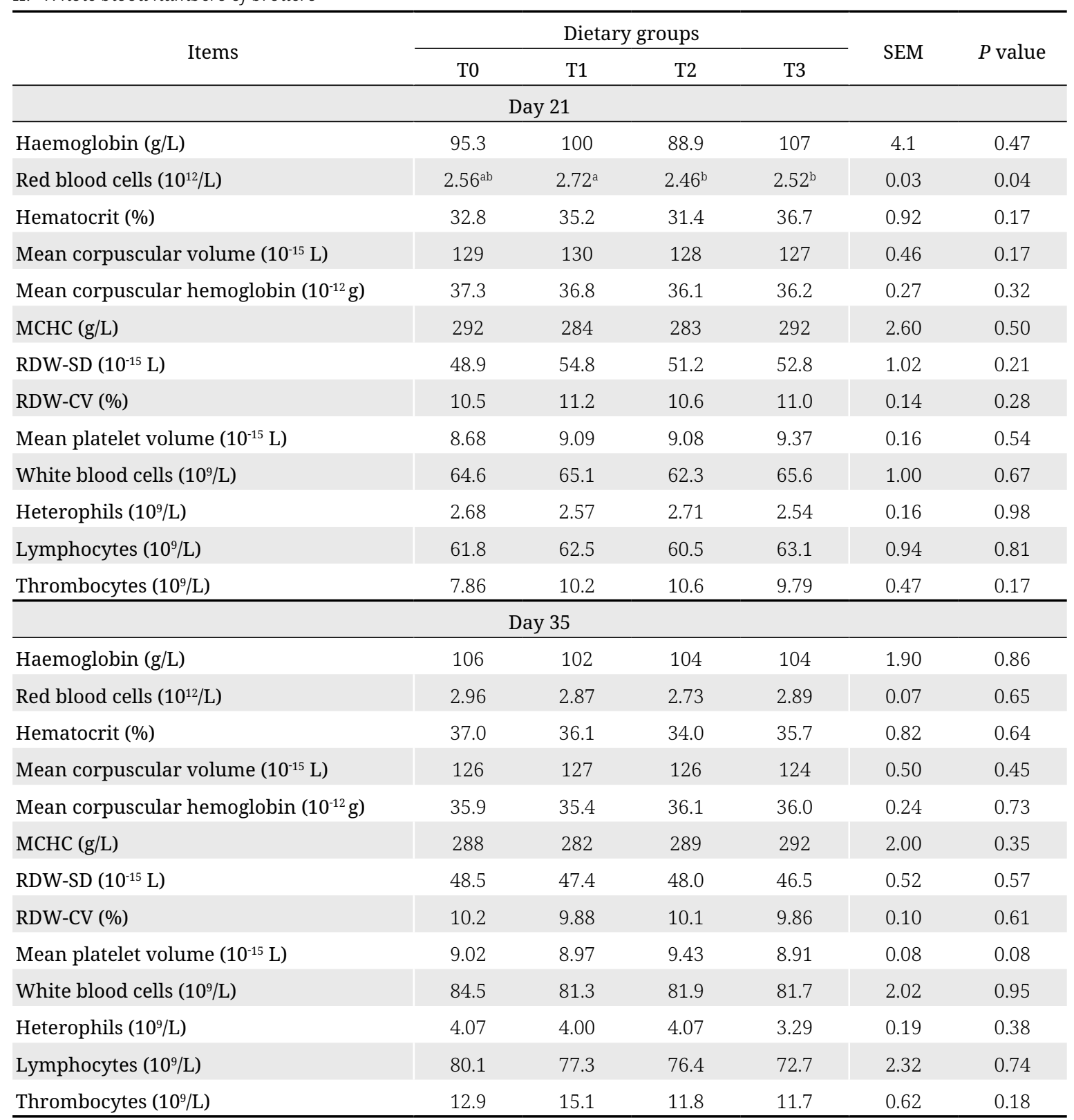

a,b Values having various letters inside the same row are significantly distinct

T0: control (additive free diet), T1: diet administrated with 1\% lactic fermented turmeric, T2: $1 \%$ lactic fermented black pepper, T3: 1\% lactic fermented turmeric and 1\% lactic fermented black pepper, MCHC: mean corpuscular hemoglobin concentration, RDW-SD: red blood cell distribution width-standard deviation, RDW-CV: red blood cell distribution widthcoefficient variation 


\section{Biochemical Traits and Antibody Against NDV in Serum of Broilers}

Tab. III shows the detailed serum biochemical indices of broilers. On day 21, broilers at $\mathrm{T} 1$ had less $(P \leq 0.05)$ total serum triglycerides in comparison to T0 and T3, but not different $(P>0.05)$ from T2. Globulin levels were decreased $(P \leq 0.05)$ in T3 than in T0 and T1, but did not vary $(P>0.05)$ from T2. On day 35 , serum total triglyceride values were elevated $(P \leq 0.05)$ at T0 compared to that in T2 and T3, but not divergent $(P>0.05)$ from T1. The concentrations of cholesterol as well as LDL were reduced $(P \leq 0.05)$ at T3 than at T0, but not different $(P>0.05)$ from T1 and T2. In comparison to other broilers, total serum protein and also globulin concentrations were lower $(P \leq 0.05)$ at T3. The ratio of albumin to globulin (A/G) was elevated $(P \leq 0.05)$ in T3 than in T1 and T2, but not divergent $(P>0.05)$ from $\mathrm{T} 0$. The concentration of creatinine was enhanced $(P \leq 0.05)$ at $\mathrm{T} 1$ than in the other broiler groups.

On day 35 , the titer to NDV was greater $(P \leq 0.05)$ in blood of T1 and T2 when compared with that in T0 chicks (Tab. IV). Antibody titers were, however, not divergent $(P>0.05)$ across groups at measurement on day 21.

\section{pH Values and Intestinal Bacterial Counts of Broilers}

The data on $\mathrm{pH}$ values of intestinal segments of chickens are provided in Tab. V. Overall, the lack influence $(P>0.05)$ of diets on the $\mathrm{pH}$ of gut segments of broilers was observed.

III: Serum biochemical indices of broilers

\begin{tabular}{|c|c|c|c|c|c|c|}
\hline \multirow{2}{*}{ Items } & \multicolumn{4}{|c|}{ Dietary groups } & \multirow{2}{*}{ SEM } & \multirow{2}{*}{$P$ value } \\
\hline & T0 & $\mathrm{T} 1$ & $\mathrm{~T} 2$ & $\mathrm{~T} 3$ & & \\
\hline \multicolumn{7}{|c|}{ Day 21} \\
\hline Total triglyceride (g/L) & $1.27^{\mathrm{a}}$ & $0.95^{\mathrm{b}}$ & $1.08^{a b}$ & $1.22^{\mathrm{a}}$ & 0.04 & 0.04 \\
\hline Total cholesterol (g/L) & 1.41 & 1.36 & 1.30 & 1.37 & 0.03 & 0.53 \\
\hline Low-density lipoprotein (g/L) & 0.41 & 0.23 & 0.24 & 0.24 & 0.04 & 0.36 \\
\hline High-density lipoprotein (g/L) & 0.90 & 1.01 & 0.96 & 0.90 & 0.03 & 0.37 \\
\hline Total protein (g/L) & 27.8 & 27.9 & 27.4 & 25.3 & 0.50 & 0.16 \\
\hline Albumin (g/L) & 12.6 & 12.7 & 12.7 & 12.1 & 0.20 & 0.70 \\
\hline Globulin (g/L) & $15.1^{\mathrm{a}}$ & $15.2^{\mathrm{a}}$ & $14.8^{\mathrm{ab}}$ & $13.2^{\mathrm{b}}$ & 0.30 & 0.04 \\
\hline $\mathrm{A} / \mathrm{G}$ ratio & 0.84 & 0.85 & 0.86 & 0.92 & 0.01 & 0.12 \\
\hline Aspartate aminotransferase (U/L) & 236 & 226 & 211 & 206 & 4.63 & 0.08 \\
\hline Alanine aminotransferase (U/L) & 2.99 & 2.91 & 2.63 & 2.11 & 0.21 & 0.45 \\
\hline Uric acid (g/L) & 0.09 & 0.10 & 0.08 & 0.07 & 0.05 & 0.14 \\
\hline Creatinine $\left(10^{-2} \mathrm{~g} / \mathrm{L}\right)$ & 0.07 & 0.11 & 0.08 & 0.06 & 0.01 & 0.45 \\
\hline \multicolumn{7}{|c|}{ Day 35} \\
\hline Total triglyceride (g/L) & $1.14^{\mathrm{a}}$ & $1.04^{\mathrm{ab}}$ & $0.95^{\mathrm{b}}$ & $0.87^{\mathrm{b}}$ & 0.03 & 0.02 \\
\hline Total cholesterol (g/L) & $1.52^{\mathrm{a}}$ & $1.42^{\mathrm{ab}}$ & $1.40^{\mathrm{ab}}$ & $1.31^{\mathrm{b}}$ & 0.02 & 0.02 \\
\hline Low-density lipoprotein (g/L) & $0.43^{a}$ & $0.33^{\mathrm{ab}}$ & $0.26^{\mathrm{ab}}$ & $0.21^{\mathrm{b}}$ & 0.03 & 0.04 \\
\hline High-density lipoprotein (g/L) & 0.88 & 0.88 & 0.89 & 0.95 & 0.02 & 0.67 \\
\hline Total protein (g/L) & $35.1^{\mathrm{a}}$ & $34.0^{\mathrm{a}}$ & $33.8^{\mathrm{a}}$ & $30.1^{\mathrm{b}}$ & 0.50 & $<0.01$ \\
\hline Albumin (g/L) & 14.2 & 13.4 & 12.9 & 12.2 & 0.30 & 0.09 \\
\hline Globulin (g/L) & $21.0^{\mathrm{a}}$ & $20.6^{a}$ & $21.6^{\mathrm{a}}$ & $17.3^{\mathrm{b}}$ & 0.50 & $<0.01$ \\
\hline $\mathrm{A} / \mathrm{G}$ ratio & $0.68^{\mathrm{ab}}$ & $0.66^{\mathrm{b}}$ & $0.59^{\mathrm{b}}$ & $0.78^{a}$ & 0.02 & 0.02 \\
\hline Aspartate aminotransferase (U/L) & 291 & 302 & 268 & 276 & 5.94 & 0.18 \\
\hline Alanine aminotransferase (U/L) & 2.03 & 1.57 & 0.87 & 0.97 & 0.18 & 0.06 \\
\hline Uric acid (g/L) & 0.07 & 0.07 & 0.08 & 0.06 & 0.01 & 0.59 \\
\hline Creatinine $\left(10^{-2} \mathrm{~g} / \mathrm{L}\right)$ & $0.07^{\mathrm{b}}$ & $0.09^{a}$ & $0.07^{\mathrm{b}}$ & $0.06^{c}$ & $<0.01$ & $<0.01$ \\
\hline
\end{tabular}

a,b Values having various letters inside the same row are significantly distinct

T0: control (additive free diet), T1: diet administrated with 1\% lactic fermented turmeric, T2: 1\% lactic fermented black pepper, T3: $1 \%$ lactic fermented turmeric and 1\% lactic fermented black pepper, A/G ratio: albumin to globulin ratio 
IV: Antibody titer against NDV in serum of broilers

\begin{tabular}{lcccccccc}
\hline & \multicolumn{9}{c}{ Dietary groups } & \multirow{2}{*}{ SEM } & \multirow{2}{*}{$P$ value } \\
\cline { 2 - 6 } & Items $\left(\log _{2}\right.$ GMT) & T0 & T1 & T2 & T3 & & & 0.31 \\
\hline Day 21 & 1.36 & 0.86 & 1.50 & 1.36 & 0.13 & 0.03 \\
\hline Day 35 & $1.21^{\mathrm{c}}$ & $2.93^{\mathrm{a}}$ & $2.57^{\mathrm{ab}}$ & $1.57^{\mathrm{bc}}$ & 0.24 & 0.24 \\
\hline
\end{tabular}

a,b,c Values having various letters inside the same row are significantly distinct

T0: control (additive free diet), T1: diet administrated with 1\% lactic fermented turmeric, T2: 1\% lactic fermented black pepper, T3: 1\% lactic fermented turmeric and 1\% lactic fermented black pepper, GMT: geometric mean titer

V: pH values of intestinal segments of broilers

\begin{tabular}{lcccccccc}
\hline & Items & \multicolumn{9}{c}{ Dietary groups } & \multirow{2}{*}{ SEM } & \multirow{2}{*}{$P$ value } \\
\cline { 2 - 6 } & & T0 & T1 & T2 & T3 & & & 0.96 \\
Duodenum & 6.14 & 6.16 & 6.14 & 6.10 & & 0.04 & 0.18 \\
Jejunum & 5.59 & 5.61 & 5.57 & 5.35 & 0.05 & 0.18 \\
Ileum & 5.46 & 5.17 & 5.27 & 5.27 & 0.07 & 0.60 \\
Caecum & 6.97 & 6.82 & 6.78 & 7.22 & 0.10 & 0.37 \\
\hline
\end{tabular}

T0: control (additive free diet), T1: diet administrated with 1\% lactic fermented turmeric, T2: $1 \%$ lactic fermented black pepper, T3: 1\% lactic fermented turmeric and 1\% lactic fermented black pepper

VI: Selected bacterial counts of ileum and caecum of broilers

\begin{tabular}{|c|c|c|c|c|c|c|}
\hline \multirow{2}{*}{ Items (log cfu/g) } & \multicolumn{4}{|c|}{ Dietary groups } & \multirow{2}{*}{ SEM } & \multirow{2}{*}{$P$ value } \\
\hline & T0 & $\mathrm{T} 1$ & $\mathrm{~T} 2$ & $\mathrm{~T} 3$ & & \\
\hline \multicolumn{7}{|c|}{ Ileum } \\
\hline Coliform & 5.51 & 5.65 & 6.26 & 5.73 & 0.16 & 0.38 \\
\hline LNE & 6.80 & 5.93 & 6.34 & 6.09 & 0.22 & 0.55 \\
\hline Enterobacteriaceae & 6.82 & 6.15 & 6.47 & 6.09 & 0.23 & 0.67 \\
\hline Lactic acid bacteria & $9.37^{b}$ & $10.5^{\mathrm{a}}$ & $10.3^{\mathrm{a}}$ & $9.96^{\mathrm{ab}}$ & 0.14 & 0.03 \\
\hline \multicolumn{7}{|c|}{ Caecum } \\
\hline Coliform & 7.92 & 6.71 & 6.94 & 6.85 & 0.24 & 0.28 \\
\hline LNE & 7.45 & 6.42 & 6.98 & 7.49 & 0.26 & 0.43 \\
\hline Enterobacteriaceae & 7.96 & 6.93 & 7.28 & 7.81 & 0.27 & 0.53 \\
\hline Lactic acid bacteria & 11.7 & 11.5 & 11.6 & 11.6 & 0.05 & 0.79 \\
\hline
\end{tabular}

a,b Values having various letters inside the same row are significantly distinct

T0: control (additive free diet), T1: diet administrated with 1\% lactic fermented turmeric, T2: 1\% lactic fermented black pepper, T3: 1\% lactic fermented turmeric and 1\% lactic fermented black pepper, LNE: lactose negative enterobacteriaceae

The population of LAB were elevated $(P \leq 0.05)$ in ileal content of T1 and T2 than that in T0, but were did not vary $(P>0.05)$ from T3 broilers (Tab. VI). The counts of LAB in caecal digesta were not divergent $(P>0.05)$ amongst broilers. The counts of coliform, lactose negative enterobacteriaceae and Enterobacteriaceae were not distinct $(P>0.05)$ both in ileum and caecum.

\section{Gut Morphology of Broilers}

The results of chicken intestine morphology are presented in Tab. VII. Compared with T0, jejunal villi height was enhanced $(P \leq 0.05)$ in $\mathrm{T} 1, \mathrm{~T} 2$ and T3 broilers. However, the height of villus, depth of crypt and ratio of villous height to crypt depth
$(\mathrm{VH} / \mathrm{CD})$ did not differ $(P>0.05)$ in the duodenum and ileum in broiler chickens.

\section{DISCUSSION}

At day 21, the numbers of erythrocytes were higher in T1 than that in T2 and T3, but were not divergent from $\mathrm{T} 0$. It has generally been known that erythrocytes are responsible for transporting oxygen to the entire body cells. Hence, the lower concentration of erythrocytes may implicate in the lower oxygen supply to the cells, which may negatively affect the metabolic process in animals. The latter condition resulted in reduced energy production for growth of broiler chickens. In this 
VII: Intestinal morphology of broilers

\begin{tabular}{|c|c|c|c|c|c|c|}
\hline \multirow{2}{*}{ Items $(\mu \mathrm{m})$} & \multicolumn{4}{|c|}{ Dietary groups } & \multirow{2}{*}{ SEM } & \multirow{2}{*}{$P$ value } \\
\hline & T0 & $\mathrm{T} 1$ & $\mathrm{~T} 2$ & $\mathrm{~T} 3$ & & \\
\hline \multicolumn{7}{|c|}{ Duodenum } \\
\hline Villi height & 1031 & 1189 & 1239 & 1161 & 36.8 & 0.24 \\
\hline Crypt depth & 128 & 118 & 145 & 140 & 5.59 & 0.34 \\
\hline $\mathrm{VH} / \mathrm{CD}$ & 9.55 & 10.3 & 9.04 & 9.16 & 0.44 & 0.74 \\
\hline \multicolumn{7}{|c|}{ Jejunum } \\
\hline Villi height & $761^{\mathrm{b}}$ & $975^{a}$ & $1012^{\mathrm{a}}$ & $1034^{\mathrm{a}}$ & 39.6 & 0.05 \\
\hline Crypt depth & 99.1 & 103 & 112 & 104 & 3.76 & 0.69 \\
\hline $\mathrm{VH} / \mathrm{CD}$ & 8.34 & 9.59 & 9.45 & 10.4 & 0.45 & 0.47 \\
\hline \multicolumn{7}{|c|}{ Ileum } \\
\hline Villi height & 614 & 595 & 635 & 607 & 15.4 & 0.85 \\
\hline Crypt depth & 98.4 & 100 & 101 & 91.1 & 3.61 & 0.78 \\
\hline $\mathrm{VH} / \mathrm{CD}$ & 6.81 & 6.17 & 6.69 & 6.81 & 0.25 & 0.78 \\
\hline
\end{tabular}

a,b Values having various letters inside the same row are significantly distinct

T0: control (additive free diet), T1: diet administrated with 1\% lactic fermented turmeric, T2: 1\% lactic fermented black pepper, T3: 1\% lactic fermented turmeric and 1\% lactic fermented black pepper, VH/CD: ratio of villus height to crypt depth

study, the final body weight (at day 35) of broilers were 1569, 1561, 1443 and $1387 \mathrm{~g}$ for T0, T1, T2 and T3, respectively. Previous study documented that dietary administration with black pepper resulted in reduction in erythrocyte numbers of broilers (Al-Kassie et al., 2011). The latter investigators further inferred that black pepper may activate estrogen activity in broilers. Indeed, Khan and Zafar (2005) reported that the increased estrogen activity was associated with the decreased erythrocyte counts in broilers, which is the result of the elevated hemodilution. In the previous study, Nourmohammadi and Khosravinia (2015) noticed an over acidification due to dietary provision of $60 \mathrm{~g} / \mathrm{kg}$ of citric acid leading to deleterious effect on the physiological conditions of broilers. In this study, the high levels of fermented herbal mixture in diets (2\% of diet) may exert acidic stress and thereby adversely influence erythropoiesis (Xu et al., 2018). However, these above inferences must be interpreted with careful as the counts of erythrocytes did not vary across the treatment groups of broilers at day 35.

At day 21, broilers in $\mathrm{T} 1$ had a lower serum total triglyceride concentration than that of T0 and T3. However, the condition was not consistent at day 35 as T2 and T3 had lower serum total triglyceride than that of T0, while T1 did not vary from T0, T2 and T3 groups. Moreover, broiler in T3 group had lower total cholesterol and LDL concentrations in serum as compared to that in T0 group. With regard to the single use of herb as feed additive, Abou-Elkhair et al. (2014) and Adegoke et al. (2018) revealed the absent impact of turmeric powder on serum total cholesterol and LDL levels of broiler. Likewise,
Abou-Elkhair et al. (2014) found no influence of black pepper meal on the serum levels of total triglyceride and cholesterol of broiler in their study. Owing to these facts, the synergistic effect of fermented turmeric and black pepper seemed to be attributed to the lipid-lowering activity of the herbal mixture as the individual use of fermented turmeric or black pepper powder resulted only in moderate decrease in cholesterol and LDL levels in the present study. Another possibilities could be that the high acidity in the herbal mixture may reduce blood lipid of broilers as Moghadam et al. (2009) and Ghazvinian et al. (2018) noticed that feeding organic acid decreased total triglyceride, cholesterol and LDL in chicken blood. It was apparent in the present investigation that T3 birds had lower serum total protein at day 35. Kapelanski et al. (2004) noted the positive relationship between serum total protein and growth rate of animal. In this context, the lower serum total protein in T3 seemed to imply in the lower final body weight of the respective birds, as confirmed in the above paragraph. With regard to globulin, broilers in T3 group had lower serum globulin concentration than that of other groups of broilers. Recent report by Ismail et al. (2020) pointed out that the higher serum globulin value was identical with the improved immunity of broiler chickens, since globulin is a precursor for immunoglobulin synthesis. In this study, the lower serum globulin level in T3 was associated with the relatively lower antibody titer against Newcastle disease vaccine, especially when compared with that of $\mathrm{T} 1$ at day 35. In support to the fact above, the higher $\mathrm{A} / \mathrm{G}$ ratio in $\mathrm{T} 3$ may also indicate the lower disease resistance of the birds as formerly 
confirmed by Abdel-Fattah et al. (2008). Former investigation by Haider et al. (1977) reported the decreased gamma-globulin concentration in rats exposed to stress. In this study, the high levels of fermented herbal mixture (2\% of diet) may exert acidic stress (Nourmohammadi and Khosravinia, 2015), which consequently attenuate the globulin synthesis. The level of creatinine was higher in T1 compared to other treatment groups, with T3 group had the lowest concentration. In general, the blood level of creatinine is associated with the function of kidney and also the extent of protein break down (Del Vesco et al., 2015). In this regard, the increased creatinine level in the blood of broilers seemed to be attributed to the deficiency of kidney. However, the level of serum creatinine in this experiment was still within the acceptable range as Sugiharto et al. (2019) noted that the serum creatinine concentration of broilers ranged from 0.05 to $0.10 \mathrm{mg} / \mathrm{dL}$.

At day 35, antibody titer to NDV was elevated in serum of $\mathrm{T} 1$ and $\mathrm{T} 2$ than that in $\mathrm{T} 0$ birds. This may implicate in better resistance of $\mathrm{T} 1$ and $\mathrm{T} 2$ broiler chickens against Newcastle disease. In the previous study, Abou-Elkhair et al. (2014) documented no substantial impact of turmeric and black pepper on antibody toward NDV in broiler chickens. Owing to this, lactic fermentation using $A$. bilimbi L. fruit filtrate seemed to improve the immune-enhancing effect of turmeric and black pepper powder. The presence of LAB (Salehizadeh et al., 2019) and also the improvement in the biological activities of the herbs (Daliri et al., 2019) following the lacticfermentation may be associated to the immune enhancing properties of turmeric and black pepper powder in the current investigation. With regard to $\mathrm{T} 3$, the mixture of fermented turmeric and black pepper did not increase the antibody response of broilers. In this case, the high levels of fermented herbs ( $2 \%$ of diet) could be a stressor (Nourmohammadi and Khosravinia, 2015), which may then attenuate the immune-stimulating effect of the herbs on broiler chickens.

It is generally known that the $\mathrm{pH}$ values of the intestine depend on several factors, one of which is the characteristics of the diets. Previously, Loh et al. (2007) showed that feeding diets containing fermented product reduced the $\mathrm{pH}$ values of the excreta of laying hens. In the present study, dietary administration of fermented of turmeric, black pepper or the combination of both did not result in the alteration of $\mathrm{pH}$ values of the intestinal segments of broiler chickens. The definite reason for the lacking effect of dietary administration of fermented herbs on the intestinal pH was not known. However, the buffering activity of the intestine in response to the incoming fermented herbs may stabilize the $\mathrm{pH}$ values of the intestinal tract of broilers (Pearlin et al., 2020).

Dietary administration of fermented turmeric or black pepper enhanced the counts of ileal LAB of broilers. In agreement, Qiao et al. (2018) reported that dietary administration of fermented Astragalus improved the bacterial population in the intestine of broiler, i.e., increased the Lactobacillus sp. and decreased pathogenic bacteria populations. The latter investigators suggested that lactic fermentation may produce substantial amount of organic acids, which are beneficial for the proliferation of good bacteria, for instance LAB. Likewise, the presence of LAB in the fermented product may increase the counts of LAB in the intestine of chickens (Qiao et al., 2018; Salehizadeh et al., 2019).

It was shown that $\mathrm{T} 1, \mathrm{~T} 2$ and $\mathrm{T} 3$ had higher jejunal villi height than that of $\mathrm{TO}$ broilers. Considering the important role of jejunal villi in absorbing the nutrients derived from feed, the enhanced villi height may therefore be expected to improve the absorptive capacity of the jejunum. The explanation for the improving effect of fermented herbs on the intestinal morphology was not definitely known. Previous studies suggested that curcumin in turmeric (Rajput et al., 2013) and black pepper (Oso et al., 2019) may reduce the pathogenic bacterial load and thus improve the intestinal morphology of broilers. The minimum pathogen load could be attributed to the less tissue damage and inflammation, which thereby maintain the intestinal integrity of chicks (Rajput et al., 2013). The acidic effect of fermented herbs may also be associated with the enhanced intestinal villi height as Sabour et al. (2019) documented that feeding organic acid increased the jejunal villi height of broilers. The latter investigators further noticed that acidic condition may favour the increased LAB population and hence improve the intestinal ecology and villi development.

\section{CONCLUSION}

Dietary administration of fermented turmeric powder improved erythrocyte counts, antibody titer toward NDV, LAB population and jejunal villi height of broilers. The mixture of fermented turmeric and black pepper improved blood lipid profile and jejunal villi height, but had no improving-effect on the intestinal LAB population and immune response of broilers.

Acknowledgements

The experiment was fully sponsored by Universitas Diponegoro, contract No. 233-23/UN7.6.1/PP/2020. 


\section{REFERENCES}

ABDEL-FATTAH, S. A., EL-SANHOURY, M. H., EL-MEDNAY, N. M. and ABDEL-AZEEM, F. 2008. Thyroid activity, some blood constituents, organs morphology and performance of broiler chicks fed supplemental organic acids. International Journal of Poultry Science, 7(3): 215-222.

ABOU-ELKHAIR, R., AHMED, H. A. and SELIM, S. 2014. Effects of black pepper (Piper Nigrum), turmeric powder (Curcuma Longa) and coriander seeds (Coriandrum Sativum) and their combinations as feed additives on growth performance, carcass traits, some blood parameters and humoral immune response of broiler chickens. Asian-Australasian Journal of Animal Sciences, 27(6): 847-854.

ADEGOKE, A. V., ABIMBOLA, M. A., SANWO, K. A., EGBEYALE, L. T., ABIONA, J. A., OSO, A. O. and IPOSU, S. O. 2018. Performance and blood biochemistry profile of broiler chickens fed dietary turmeric (Curcuma longa) powder and cayenne pepper (Capsicum frutescens) powders as antioxidants. Veterinary and Animal Science, 6(2018): 95-102.

ALHASSAN, A. M. and AHMED, Q. U. 2016. Averrhoa bilimbi Linn.: A review of its ethnomedicinal uses, phytochemistry, and pharmacology. Journal of Pharmacy and Bioallied Sciences, 8(4): 265-271.

AL-KASSIE, G. A. M., AL-NASRAWI, M. A. M. and AJEENA, S. J. 2011. Use of black pepper (Piper nigrum) as feed additive in broilers diet. Research Opinions in Animal and Veterinary Sciences, 1(3): 169-173.

ATTIA, Y. A., AL-HARTHI, M. A. and HASSAN, S. S. 2017. Turmeric (Curcuma longa Linn.) as a phytogenic growth promoter alternative for antibiotic and comparable to mannan oligosaccharides for broiler chicks. Revista Mexicana de Ciencias Pecuarias, 8(1): 11-21.

BOLTON, W. 1967. Poultry nutrition. MAFF Bulletin No. 174. London: HMSO.

DALIRI, E. B.-M., KIM, S.-H., PARK, B.-J., KIM, H.-S., KIM, J.-M., KIM, H. S. and OH, D.-H. 2019. Effects of different processing methods on the antioxidant and immune stimulating abilities of garlic. Food Science and Nutrition, 7(4): 1222-1229.

DEL VESCO, A. P., GASPARINO, E., GRIESER, D. O., ZANCANELA, V., VOLTOLINI, D. M., KHATLAB, A. S., GUIMARÃES, S. E. F., SOARES, M. A. M. and NETO, A. R. O. 2015. Effects of methionine supplementation on the expression of protein deposition-related genes in acute heat stress-exposed broilers. PLoS ONE, 10(2): e0115821.

GHAZVINIAN, K., SEIDAVI, A., LAUDADIO, V., RAGNI, M. and TUFARELLI, V. 2018. Effects of various levels of organic acids and of virginiamycin on performance, blood parameters, immunoglobulins and microbial population of broiler chicks. South African Journal of Animal Science, 48(5): 961-967.

GUIL-GUERRERO, J. L., RAMOS, L., ZÚÑIGA PAREDES, J. C., CARLOSAMA-YÉPEZ, M., MORENO, C. and RUALES, P. 2017. Effects of turmeric rhizome powder and curcumin. A review. Journal of Animal and Feed Sciences, 26(4): 293-302.

HAIDER, M., KANZ, G., KOLLER, M. and SCHMID, H. 1977. Stress-induced blood protein and blood lipid changes and their dependence on learning and conditioning. Wien Klin Wochenschr, 89(1): 18-23.

ISMAIL, I. E., ALAGAWANY, M., TAHA, A. E., PUVAČA, N., LAUDADIO, V. and TUFARELLI, V. 2020. Effect of dietary supplementation of garlic powder and phenyl acetic acid on productive performance, blood haematology, immunity and antioxidant status of broiler chickens. Animal Bioscience, 00(00): $1-8$.

KAPELAŃSKI, W., GRAJEWSKA, S., BOCIAN, M., DYBAŁA, J., JANKOWIAK, H. and WIŚNIEWSKA, J. 2004. Changes in blood biochemical indicators during fattening of the high-lean pigs. Animal Science Papers and Reports, 22(4): 443-449.

KHAN, T. A. and ZAFAR, F. 2005. Haematological study in response to varying doses of estrogen in broiler chicken. International Journal of Poultry Science, 4(10): 748-751.

LOH, T. C., LAW, F. L., FOO, H. L., GOH, Y. M. and ZULKIFLI, I. 2007. Effects of feeding a fermented product on egg production, faecal microflora and faecal $\mathrm{pH}$ in laying hens. Journal of Animal and Feed Sciences, 16(3): 452-462.

MARETA, I., NATHANIEL, G., YUDIARTI, T., WIDIASTUTI, E., WAHYUNI, H. I. and SUGIHARTO, S. 2020. Effect of Averrhoa bilimbi fruit filtrate and shrimp paste mixture on performance, gut microbes and blood profile of broilers. Indonesian Journal of Animal and Veterinary Sciences, 25(4): 182-189.

MOGHADAM, M. H. B., REZAEI, M., NIKNAFS, F. and SAYYAHZADEH, H. 2009. Effect of combined probiotic and organic acid on some blood parameters and immune system of broiler chicks. In: $2^{\text {th }}$ Mediterraean Summit of WPSA. Antalya Turkey, 4-7 October 2009.

NAZARNI, R., PURNAMA, D., UMAR, S. and ENI, H. 2016. The effect of fermentation on total phenolic, flavonoid and tannin content and its relation to antibacterial activity in jaruk tigarun (Crataeva nurvala, Buch HAM). International Food Research Journal, 23(1): 309-315.

NDELEKWUTE, E. K., AFOLABI, K. D., UZEGBU, H. O., UNAH, U. L. and AMAEFULE, K. U. 2015. Effect of dietary Black pepper (Piper nigrum) on the performance of broiler. Bangladesh Journal of Animal Science, 44(2): 120-127. 
NG, C.-C., WANG, C.-Y., WANG, Y.-P., TZENG, W.-S. and SHYU, Y.-T. 2011. Lactic acid bacterial fermentation on the production of functional antioxidant herbal Anoectochilus formosanus Hayata. Journal of Bioscience and Bioengineering, 111(3): 289-293.

NOURMOHAMMADI, R. and KHOSRAVINIA, H. 2015. Acidic stress caused by dietary administration of citric acid in broiler chickens. Archives Animal Breeding, 58(2): 309-315.

OSO, A. O., SUGANTHI, R. U., REDDY, G. B. M., MALIK, P. K., THIRUMALAISAMY, G., AWACHAT, V. B., SELVARAJU, S., ARANGASAMY, A. and BHATTA, R. 2019. Effect of dietary supplementation with phytogenic blend on growth performance, apparent ileal digestibility of nutrients, intestinal morphology, and cecal microflora of broiler chickens. Poultry Science, 98(10): 4755-4766.

PERIS, C., SINGH, K. and DSOUZA, M. 2013. Nutritional and biochemical evaluation of Averrhoa bilimbi L. Archives of Pharmacy and Biological Sciences, 1(2): 58-62.

PEARLIN, B. V., MUTHUVEL, S., GOVIDASAMY, P., VILLAVAN, M., ALAGAWANY, M., RAGAB FARAG, M., DHAMA, K. and GOPI, M. 2020. Role of acidifiers in livestock nutrition and health: A review. Journal of Animal Physiology and Animal Nutrition, 104(2): 558-569.

PUVAČA, N., KOSTADINOVIĆ, L., LJUBOJEVIĆ, D., LUKAČ, D. and POPOVIĆ, S. 2014. Influence of black pepper (Piper nigrum L.) on productive performances and blood lipid profile of broiler chickens. Annals of Biological Research, 5(12): 29-33.

QIAO, H., SONG, Y., SHI, H. and BIAN, C. 2018. Fermented Astragalus in diet altered the composition of fecal microbiota in broiler chickens. AMB Express, 8: 151.

RAJPUT, N., MUHAMMAD, N., YAN, R., ZHONG, X. and WANG, T. 2013. Effect of dietary supplementation of curcumin on growth performance, intestinal morphology and nutrients utilization of broiler chicks. Journal of Poultry Science, 50(1): 44-52.

RIZZELlO, C. G., CODA, R., MACÍAS, D. S., PINTO, D., MARZANI, B., FILANNINO, P., GIULIANI, G., PARADISO, V. M., DI CAGNO, R. and GOBBETTI, M. 2013. Lactic acid fermentation as a tool to enhance the functional features of Echinacea spp. Microbial Cell Factories, 12: 44.

RODRÍGUEZ, L. G. R., MOHAMED, F., BLECKWEDEL, J., MEDINA, R., DE VUYST, L., HEBERT, E. M. and MOZZI, F. 2019. Diversity and functional properties of lactic acid bacteria isolated from wild fruits and flowers present in Northern Argentina. Frontiers in Microbiology, 10: 1091.

SABOUR, S., TABEIDIAN, S. A. and SADEGHI, G. 2019. Dietary organic acid and fiber sources affect performance, intestinal morphology, immune responses and gut microflora in broilers. Animal Nutrition, 5: 156-162.

SALEHIZADEH, M., MODARRESSI, M. H., MOUSAVI, S. N. and EBRAHIMI, M. T. 2019. Effects of probiotic lactic acid bacteria on growth performance, carcass characteristics, hematological indices, humoral immunity, and IGF-I gene expression in broiler chicken. Tropical Animal Health and Production, 51(8): 2279-2286.

SUGIHARTO, S., YUDIARTI, T. and ISROLI, I. 2019. Growth performance, haematological parameters, intestinal microbiology, and carcass characteristics of broiler chickens fed two-stage fermented cassava pulp during finishing phase. Tropical Animal Science Journal, 42(2): 113-120.

ÜRÜŞAN, H. and BÖLÜKBAŞI, Ş. C. 2017. Effects of dietary supplementation levels of turmeric powder (Curcuma longa) on performance, carcass characteristics and gut microflora in broiler chickens. The Journal of Animal \& Plant Sciences, 27(3): 732-736.

VILLEGAS, P. 1987. Avian virus diseases laboratory manual. Athens, Georgia, USA: College of Veterinary Medicine. University of Georgia

XU, Y., LAI, X., LI, Z., ZHANG, X. and LUO, Q. 2018. Effect of chronic heat stress on some physiological and immunological parameters in different breed of broilers. Poultry Science, 97(11): 4073-4082.

Contact information

Sugiharto Sugiharto: sgh_undip@yahoo.co.id 